\title{
Hegel and Colonialism
}

\author{
Alison Stone
}

\begin{abstract}
This article explores the implications of Hegel's Philosophy of World History with respect to colonialism. For Hegel, freedom can be recognized and practised only in classical, Christian and modern Europe; therefore, the world's other peoples can acquire freedom only if Europeans impose their civilization upon them. Although this imposition denies freedom to colonized peoples, this denial is legitimate for Hegel because it is the sole condition on which these peoples can gain freedom in the longer term. The article then considers whether Hegel's basic account of freedom can be extricated from his Eurocentric and pro-colonialist interpretation of the course of history. The article argues that matters are more complicated because that interpretation has significant connections with Hegel's conception of freedom as self-determination.
\end{abstract}

Recently there has been considerable discussion amongst Hegel scholars of Hegel's views on race. ${ }^{1}$ There has been less direct consideration of what Hegel thought or what his philosophy implies regarding colonialism, ${ }^{2}$ even though the discourses of race, colonialism and Eurocentrism are entwined. In this article I reconstruct Hegel's position on colonialism-taking 'colonialism' to mean the system of European political and economic dominance over the rest of the world which began to form when Columbus and others arrived in North and South America, culminated in the 'scramble for Africa' in the late nineteenth century, and lasted into the mid-twentieth century.

To reconstruct Hegel's position on colonialism I focus on his Philosophy of World History (PWH), for reasons explained in Section I, in which I re-examine the Eurocentrism of the PWH's essential claims. In Section II, I explain how the PWH implies that colonialism is justified on the grounds that it spreads the principle and spirit of freedom. For Hegel, it has only been possible for this principle to be grasped and put into practice in Europe. Therefore, the world's other peoples can acquire freedom only if Europeans first impose their civilization upon them. Although this imposition denies freedom to colonized peoples, this denial is legitimate because it is the sole condition on which these 


\section{Hegel and Colonialism}

peoples can gain freedom in the longer term. Further, colonialism is necessary to the ongoing expansion of freedom which is world history's goal.

I argue, then, that Hegel's PWH generates a case for colonialism. In this I agree with critics of Hegel such as Enrique Dussel and Teshale Tibebu. They regard Hegel as a-indeed the-quintessential Eurocentrist, giving 'the most sophisticated rendition of the Eurocentric paradigm' (Tibebu 2010: xxi) and of the 'myth of modernity' (Dussel 1993) — the myth that modern Europe is the world's most advanced civilization which is obliged to educate, develop and civilize the others, using violence where this mission requires it. I also take it that:

Eurocentrism ... emerged as a discursive rationale for colonialism ... [but a]lthough colonialist discourse and Eurocentric discourse are intimately intertwined, the terms have a distinct emphasis. While the former explicitly justifies colonial practices, the latter embeds, takes for granted and 'normalizes' the hierarchical power relations generated by colonialism and imperialism, without necessarily even thematizing these issues directly. (Shohat and Stam [1994] 2014: 2)

As we will see, in Hegel's PWH overt Eurocentrism and more implicit procolonial reasoning are present in just this fashion. One might concludeassuming that colonialism was morally wrong-that there is little point studying Hegel's stance on colonialism today. I disagree, and believe such study important because the international order today remains deeply shaped by the power relations established under colonialism, so much so that this order can reasonably be described as 'neo-colonial' or as continuing to exhibit a 'coloniality of power' (Quijano 2000). In this context it is important to understand the Eurocentric and colonialist discourses that still shape the world, and to reflect critically on how some major European philosophers, including Hegel, have contributed to these discourses.

An alternative view is that it is worth studying Hegel's stance on colonialism so as to find out what resources he offers us for critiquing it. Perhaps we can filter out his basic account of freedom and its historicity from his Eurocentric narrative of the actual movement of history, and perhaps, so filtered out, his account of freedom tells against colonialism for denying freedom to many peoples. I consider this strategy for rescuing Hegel from himself in Section III, then argue in Section IV that matters are more complicated because Hegel's conception of freedom as self-determination has significant connections with his Eurocentrism and the pro-colonialism that follows from it. His philosophy nonetheless contains possibilities that can be taken in an anti-colonial direction; but it also contains elements that have real and tenacious links with colonialism, which we should not overlook. 


\section{Alison Stone}

\section{World history and Eurocentrism}

Hegel's best-known argument regarding colonialism, in his Pbilosopby of Right, is that migration of the European poor to colonies overseas can alleviate modern civil society's endemic problems of poverty and over-production (PR $\int \$ 246-48$, 267-69). ${ }^{3}$ In this article, though, I concentrate on the scattered statements on colonialism in Hegel's Philosophy of World History (PWH), along with the PWH's broader implications. ${ }^{4}$ I focus on the PWH because this is where Hegel argues that history runs from East to West, that history proper only unfolds in the West, and that Christian European civilization, especially in its latest phase as modern, liberal Europe, is the most advanced world civilization (so far, at least). That is, in the PWH Hegel overtly upholds Eurocentrism, or so I will argue in this section.

I understand Eurocentrism, informed by Shohat and Stam (2014: esp. 2-3), as the position that (i) history follows a linear path from Greece through Rome to medieval then modern Europe, all change powered internally to this line; (ii) 'modern Europe' includes European-derived cultures in the US, Australia and broadly 'the West'; (iii) inherent progress unfolds along this intra-European line towards freedom, equality and other liberal values; (iv) where unfreedom has existed or still exists in Europe's past or present, this is only because Europe has not yet fully worked through and applied its own governing principles of freedom and equality; (v) no equivalent progression to freedom and equality has occurred outside the West. This kind of position, focusing on freedom, is expressed in Hegel's PWH—his distinctive mode of approaching history notwithstandingand his Eurocentrism brings pro-colonialism in its wake, I'll argue. Thus it is from the PWH that we can best ascertain how Hegel's thought tells for colonialism.

Regarding Hegel's distinctive approach to history, suffice it here to say that Hegel's deceptively simple claim is to apply thought to history $(H 78)$ where 'the sole conception [or thought] that [philosophy] brings ... is the simple conception of reason-the conception that reason governs the world, and that therefore world history is a rational process' (79). That is, we aim to discern the immanent reason why real historical events took place: to see why it made sense for these events to happen, why they had to happen, to advance history's overarching goal: the 'consciousness of freedom' (Bewußtsein der Freiheit). This goes even for dismal episodes of decline, destruction and suffering: we ask how they too played a part in history's broader advancement. This is not a matter of imposing an external logic or categorial scheme on historical events (81) but rather of discerning their logic, through interpretation of the recorded facts. That said, we the philosophical historians bring forward the idea of reason and with it freedom-the idea that this single goal must regulate all world events—and we find that the historical 


\section{Hegel and Colonialism}

record confirms this. 'Whoever looks at the world rationally sees it as rational too; the two exist in a reciprocal relationship' (81).

As is well known, Hegel holds concretely that world history's progression in the 'consciousness of freedom' unfolds over three main stages, 'one is free', 'some are free', 'all are free' (all containing sub-divisions), corresponding to Oriental, Classical and Germanic civilizations. On 'consciousness of freedom', Hegel's views are these. Freedom consists in self-determination: rational decision-making about what ends to follow, which impulses to satisfy, or whether to act purely from universal principle instead (HG 148-49). All human individuals have this capacity for self-determination-'all human beings are intrinsically free' (an sich ... frei; $H$ 88), but individuals are not always aware of this. If they are not, then they will fail to exercise, develop and actualize their capacity, remaining practically unfree (although ontologically free)-free in themselves' (an sich) but not for themselves (88). For instance, 'the Orientals do not know that spirit, or the human being as such, is intrinsically free; because they do not know this, they are not themselves free' (87; my emphasis). As this implies, if the civilization to which I belong does not treat me as being free-say, if my place in it is to be a slave or serf-then I will be unaware of my capacity for freedom, for what I can know depends on what is known in the social world around me. This is why individual freedom advances in tandem with the shared consciousness of that freedom on the part of members of societies and as this consciousness is embodied in their practices and institutions. As this consciousness advances, the nature of freedom is grasped more adequately; its domain is expanded, e.g., from religious to secular affairs; and, crucially, its scope is expanded: ever more people and categories of people are known to be free.

As to Eurocentrism, Hegel famously states that history moves West like the sun, for history's most advanced stage is the 'Germanic' civilization whose spirit is that 'all are free'. Admittedly, for Hegel, the insight that 'all are free' was first won, albeit only in spiritual form (e.g., that we may all be saved), by Jesus Christ— thus in Judaea, not Europe (88). But Christ's message took hold in ancient Rome, not the Middle East, because the Romans already held that some are free: native male slave-holders ( $H G$ 450-51). The soil was therefore ripe for other Romans to claim that they shared in freedom too, Christianity affording them terms to do so. Next, due to Roman imperialism which spread Christianity, the Teutonic tribes encountered and gradually took on Christianity, then, after the Roman Empire fell, spread Christianity through the rest of Europe (S 347-49), becoming the 'bearers of the Christian principle of freedom' (HG 460). Through its adoption of Christianity, Europe emerged as a distinct civilization, the 'Germanic' or 'Christian'-Hegel tends to talk indifferently of the 'Christian', 'Germanic' and 'European' states (e.g., 463). 'Germanic', then, means not 'German' but 'Christian European’ more broadly (see also Mowad 2013: 168-70). 


\section{Alison Stone}

Freedom's development continued with the Reformation at last restoring the principle of the spiritual freedom of all, against previously dominant Church hierarchies. The next step, the Enlightenment, was to grasp that freedom applies in secular life too, in freedoms to own private property, choose a profession and spouse, participate in public affairs, etc. Against the excessively abstract realization of freedom in the French Revolution, the most advanced European states treat determinate social institutions-nuclear family, market economy, constitutional monarchy-as needed to secure these individual freedoms and reconcile them with social membership. Overall, then, European history has been a centuries-long process of working out and putting into practice one defining principle-the freedom of all ( $H$ 88).

Europe, then, comes to bear the Christian principle of freedom because it takes it over from the Roman Empire, where in turn Christianity had taken hold because the Romans were already conscious that 'some are free', building on the same consciousness by the ancient Greeks. So that last-the ancient Greek consciousness that 'some are free'-was ultimately decisive. 'The consciousness of freedom first awoke among the Greeks, and with that they were free' (87; my emphases); they made the key transition from unfreedom to freedom. Ultimately, this is why the development from 'some are free' to 'all are free' has only spontaneously occurred on European soil.

The transition that the Greeks made was equally from pre-history to history. Hegel says of China and India that we 'cannot speak here of a proper history as such' (HG 214). The Oriental civilizations are in world history only ambiguously. They are unhistorical insofar as they are not conscious of freedom-or rather are conscious of it only very inadequately, as belonging to one emperor (China), ruling caste (India) or empire (Persia). Consequently, individuals in these cultures are not motivated to pursue or advance their own freedom, for they do not know that they are capable of self-determination in the first place (again, the 'Orientals do not know that ... the human being as such, is intrinsically free; because they do not know this, they are not themselves free'; $H$ 87). Oriental culture contains no inner motor for progressive development to take place, by way of individuals broadening and deepening the scope of an extant yet still incomplete level of freedom. Lacking that motor, the Orient has no history properly speaking. Even so, Hegel includes the Oriental civilizations in world history because they do have a minimal level of consciousness of freedom, i.e., as belonging only to the emperor, highest caste, etc. In contrast, for Hegel, Africans and indigenous Americans lack any awareness of freedom; their worlds are fully, non-ambiguously pre-historical, whereas Oriental pre-history is on the threshold of world history and to that extent lies partly within it.

Hegel's denial of full history to the Orientals sheds light on the kind of reason he takes to be immanent in historical events, which in turn illuminates 


\section{Hegel and Colonialism}

his Eurocentrism. Whereas the Orientals lack a motor for historical development and hence are pre-historical, that motor does arise when, a given level of consciousness of freedom being attained and embodied in social life, that level of consciousness harbours some inner 'contradiction' or tension which propels people, qua rational beings, to bring about change and improvement. These conditions are first met by the ancient Greeks. Another instance, mentioned earlier, is that the Romans conferred freedom on slave-owners while denying it to slaves, giving slaves rational grounds to claim freedom as well. In Section IV we will encounter other instances of this type of historical development through the rational response to contradictions.

That reason is immanent in historical changes might suggest that in history, logical and temporal development coincide (whereas in, say, Hegel's Logic, the dialectical development of categories is not temporal). This is so to an extent. The pre-historical civilizations of Africa, indigenous America and the Orient have no consciousness of freedom sufficient to harbour self-contradictory limitations that call for change, hence these civilizations actually show no significant social change over time, for Hegel. They are and have ever been the same, embodying time but not history, that is, no instantiation over time of the dialectical-and-rational development of freedom. Conversely, in Europe the limitations placed on a freedom that is nevertheless known power developments that are at once rationally warranted and transpire, through human agency, over time. Yet, for Hegel, all that exists in space and time is subject to contingency and so realizes rational requirements under an innumerable variety of permutations arising from the very nature of a spatio-temporal, indefinitely complex, causally interconnected world (EN \250 and R, 22-24). For example, the Reformation ultimately had to happen; but it is a contingency that Luther posted his theses in Wittenberg in October $1517 .^{5}$

But not all that the PWH covers is historical. In Africa, indigenous America and the Orient, time unfolds without history. Consequently, the advancement from Africa to the Orient and from China to India to Persia occurs purely spatially, in that each region in turn grasps freedom to successive-all highly inadequate-degrees. Conversely, historical development (in Europe) takes place in space as well as time, not only in space (HG 156-57). Where advancement occurs only spatially, its motor is not human reason and agency but geographical variation. Because we are natural, spatially embodied as well as rational beings, we are inescapably located in natural surroundings that divide into continents: America, Asia, Africa and Europe. The continents' features affect how their inhabitants live and so what level of civilization and consciousness of freedom they can reach by their own efforts. America is weak and powerless, yielding immature, weak and lazy people (193). Africa is dominated by highlands and other non-cultivable areas, so that African peoples form no awareness of their 


\section{Alison Stone}

freedom, something people first develop by working on nature (196). Asia is dominated by fertile plains, so that its peoples' focus on agriculture inclines them towards patriarchal family-based relationships and uncritical obedience to authority (199-200). Only Europe is geographically diverse enough to foster people living in diverse ways and so thinking for themselves (196).

Thus, Europe's physical environment explains why Greek civilization arose and started the trajectory to modern liberalism. Conversely, for their part, the Orientals advanced beyond the Africans not by thinking rationally about the limitations of the latter's grasp of freedom-after all, allegedly they had nonebut due to the Orientals' more auspicious environmental circumstances. Ultimately, here, what guarantees the progression of stages up to the transition to history proper is the rationality that, for Hegel, is embodied in the world's geographic divisions. ${ }^{6}$ Then the European natural environment made it possible for the Greeks to form a conception of freedom that in turn enabled historical progression, in time and on the continuing basis of (intra-European) geographical space, to begin. ${ }^{7}$ (We might still ask, though, why the successive Oriental views that 'one is free' were not sufficient to initiate historical progression proper. I will return to this question later. For now let us just note that, for Hegel, they were not.)

In sum, Hegel is a Eurocentrist as defined above (p. 3). As per (i) and (iii), he believes that European civilization develops purely internally towards the fuller comprehension and application of its principle of the freedom of all, where (ii) this development has come to include that of all of the 'West', e.g., the USA. (iv) He explains oppressive episodes in European history either from its not yet having consistently worked out and applied its own principle of freedom (as with the hierarchies of the medieval church) or as unavoidable requirements for advancement (e.g., the religious wars of early modern Europe). (v) He denies that any equivalent progression to freedom has occurred or can spontaneously occur outside Europe. Next I argue that it is Hegel's Eurocentrism, in particular his sharp divide between European freedom and non-European unfreedom, which generates a case for colonialism.

\section{Hegel's case for colonialism}

In the PWH Hegel explicitly says relatively little about colonialism, but what he does say is approving. Finishing his account of the European middle ages, he praises the revival of learning, the flourishing of fine art, and the arrival of the 'hero' Columbus in the new world (S 411; Hei 204). Columbus, he says, was motivated by the 'outward' urging of spirit to know its own earth and convert non-European natives to Christianity. The reasons why Hegel regards this 


\section{Hegel and Colonialism}

positively emerge in the passages on the 'geographical conditions of history' that address the 'new world'.

It does not matter that Mexico and Peru did indeed have significant civilisations, since they were of a feebler stock and are long gone. The new world has shown itself to be much feebler than the old world. ... Some of the tribes of North America have disappeared and some have retreated and generally declined ... (HG 192-93)

In 1830/31 Hegel expanded on the new world, adding that African Negroes had to be brought to America to do the physical work of which the weak natives were incapable (Hei 59). For 'the Negroes are far more receptive to European culture than the Indians ... [and] it will still be a long time before the Europeans succeed in producing any genuine feeling of self [Selbstgefüb]' in indigenous Americans ( $S$ 81). Hegel praises the Church in Latin America for beginning to instil discipline in the natives; through these and other colonial efforts, the 'authentic Americans are ... now beginning to educate themselves [sich hineinzubilden] in European culture' ( $N$ 165). Incidentally, Hegel's points about indigenous Americans apply equally to Aboriginal Australians, since he includes 'New Holland'-i.e., Australia - in the new world.

As for the old world, Hegel begins with Africa—the 'authentic' sub-Saharan Africa of the Negroes. He contends that the Negroes know no morality and practice slavery along with polygamy, cannibalism, and other customs that embody total ignorance about freedom.

Another characteristic fact in reference to the Negroes is Slavery. Negroes are taken into slavery by Europeans and sold to America. Despite this, their lot is even worse in their own country, where an equally absolute slavery is present; for the overall foundation of slavery is that man has no consciousness of his freedom yet, and so sinks down to a mere thing, a worthless object. .... Slavery is in and for itself wrong [Unrecht], for the essence of humanity is freedom; but for this man must first become mature [reif]. This is why the gradual abolition of slavery is therefore more appropriate and more right [Ricbtigeres] than its sudden removal. (S 96-99)

So: European enslavement of Africans involves a degree of moral wrong insofar as Africans have intrinsic capacities for freedom. Yet before enslavement, Africans did not know themselves to have that capacity; accordingly they enslaved and mistreated one another, and acted merely on their natural desires. The latter does not constitute freedom, Hegel insists; if I act from naturally given 


\section{Alison Stone}

desires, I am still not determining for myself how to act. So slavery was, relatively, an improvement, because it 'matured' the Negroes to become aware of their freedom. 'One must educate the Negroes in their freedom by taming their naturalness' (Hei 70).

We can infer from Hegel's comments that slavery educates in several ways. (i) Those enslaved are subjected to European culture and ethical standards (from, e.g., $N$ 165). (ii) Slavery imposes the discipline of work (e.g., Hei 59). In working, one learns to hold one's natural desires in check and thereby see oneself as capable of deliberating about or even rejecting them. (iii) Work also instils an awareness of one's capacity to mould natural objects - a sense of 'achieving independence through one's own activity' (61). (iv) Ironically, those enslaved thus acquire a sense of private property (61) - partly by learning of European institutions of property and partly by imposing form on objects, thereby forming a sense of 'possessing' them which fosters an appreciation of property.'

In sum: 'Slavery $\ldots$ is necessary at those stages where the state [and its people] has not yet arrived at rationality. It is an element in the transition to a higher stage' (HG 197). Because slavery still has elements of wrong, though, the final step must be for slavery to end. However, Hegel cautions, slavery should not be suddenly abolished because it must end after, not before, the Negroes have been educated through it: 'If slavery was altogether wrong, then the Europeans should give the slaves their freedom immediately; but in that way the most frightening consequences arise, as in the French colonies' (Hei 70).

Hegel's line of thought, then, takes in slavery and colonization at once (understandably, since enslavement of Africans was fundamental to colonial America). Use of slavery in the colonies might be judged wrong because it violates the rights, equality and freedom of the slaves. But through being enslaved, slaves take steps forward in their consciousness of freedom which they could not otherwise make, for Africa is intrinsically pre-historical and unfree, so that freedom can come to Africans only from without. Analogously, one might think that colonization was altogether wrong because it violated the rights, equality and freedom of indigenous peoples-but no, for before colonization those people had no awareness of their freedom. They 'ha[d] no sense of private property, of achieving independence through one's own activity, or of securing one's property through right' (61). By being forced to labour and being disciplined spiritually by agencies such as the Christian church, these people will eventually learn about their freedom. Until then, their subjection, while partially wrong insofar as it is subjection, is also partially right: it is, at least, an improvement on the natives remaining in their natural, wholly unfree, pre-colonial condition.

Colonialism is justified, on this view, because it spreads freedom to peoples who otherwise both lack it and have no native means of acquiring it. Moreover, the colonizers are justified in extirpating the indigenous cultures of 


\section{Hegel and Colonialism}

native peoples-hence Hegel's endorsement of the Christian clergy and missionaries 'setting out to accustom the Indians to European culture and ethics [Sitten]' (N 164)—since those indigenous cultures embody unfreedom. We might wonder whether Hegel regards even the violence and slaughter that occurred during the colonization of America as justified. He does acknowledge European, especially Spanish, violence towards indigenous Americans, but he is only overtly critical of this violence when the colonial project had, he says, degenerated into mere robbery (Hei 204). Moreover, he disguises the extent of European violence by running together indigenous Americans having been 'destroyed and slaughtered' (untergegangen, verdrängt), having disappeared (verschwunden), and having voluntarily withdrawn (baben sich zurückgezogen; N 163; see also Parekh 2009). Hegel does not wholly denounce colonial violence because he thinks that Europe's conquest of America was based on a sound goalspreading freedom and the culture of freedom to all people-and that the violence that was necessary for achieving that goal was justified. But Hegel does disapprove of violence when it served merely an unworthy goal-robbery.

This is congruent with Hegel's overall approach to violence in history, which he memorably calls a 'slaughterbench' (Scblacbtbank). On his view, the consciousness of freedom advances through each civilization in turn establishing its pre-eminence by prevailing, culturally and militarily, over its predecessor. To the extent that war and violence are necessary for progress, they are justified (although 'justified' does not mean 'to be celebrated'). Even in these terms, though, much of the violence carried out by European colonizers-the decimation of many native American tribes, the Middle Passage-went beyond the minimum necessary to subject non-Europeans to colonial control along the way to their ultimate freedom. But likewise, in history generally, violence has regularly gone beyond the minimum necessary to propel progress. Such excesses are inevitable, an aspect of the inescapable contingency of human affairs. These excesses of violence are not justified; yet we can be reconciled to them as an inevitable, albeit non-ideal, concomitant of progress (H 90-91). Presumably, Hegel thinks the same about the excesses of colonial violence.

Hegel's overall line of thought is that colonialism is not only justified but also necessary, as part of Europe's centuries-long process of realizing freedom. A logical step in this process is to extend freedom to non-European peoples: after all, the European principle is that all are free. This extension can only occur, though, by passing through a stage of subjugating non-European peoples, since they have no native means of acquiring freedom: 'The [Negroes'] condition is incapable of any development or culture [Entwicklung und Bildung], and their condition as we see it today is as it has always been' (N 190). And 'the Negroes ... cannot move [bewegen] to any culture' (Hei 67). Likewise with indigenous Americans: America is new and young because it had no history until the 


\section{Alison Stone}

Europeans arrived. These claims do not mean that Negroes and indigenous Americans cannot be educated; they can. But given their native ignorance of freedom, they cannot educate themselves but must be educated by Europeans, which requires that they first be subjected to European control.

Hegel's case for colonization could be extended to the Orientals. He admits that unlike Africans and indigenous Americans the Oriental peoples do have an idea of freedom - that 'one is free'-but this idea remains so inadequate as to count as unfreedom. Hence, lacking belief in their own freedom, Oriental people cannot pursue any extensions or advancements of freedom and, without such pursuits to drive historical change, their societies remain ahistorical. Colonization of these peoples for educative purposes would therefore be justified. As long as a people is at a low enough level to count as unfree and pre-historical, that people can advance only through having the European spirit imposed on it, for being pre-historical it has no native way to attain freedom. And indeed Hegel does say of India that: "The English, or rather the East India Company, are the lords [Herren] of the land; for it is the necessary fate of Asiatic empires to be subjected [unterworfen] to Europeans; and China will also, some day, have to submit to this fate' (S 142-43).

We should not be misled by an apparently conflicting statement in the Philosophy of Right: 'The liberation of colonies ... [is] of the greatest advantage to the mother state, just as the emancipation of slaves is of the greatest advantage to the master' (PR \248A, 269). Hegel's paradigm here is American independence: i.e., the independence of what, he is explicit and adamant, is colonial European America, not Native America (N 165-66). That is, America merits independence once its native populace is reduced or placed securely under European tutelage. This coheres with Hegel's approving reference to independent Haiti in the Philosophy of Mind (EM \393A, 40): he says that this is a Christian state that the Negroes could only found after having undergone long spiritual servitude. Once a people has been colonized sufficiently to acquire European culture, as in Haiti, then and only then does that people merit freedom.

Hegel's argument for colonialism is of the 'civilizing mission' family. Effectively, his defence is that colonialism benefits most those who fare worst under it — colonized peoples—by civilizing and bringing them freedom that they cannot access without passing through colonial subjection. For Hegel, colonialism and the advancement of freedom go hand-in-hand.

\section{Saving Hegel from himself}

Hegel's PWH implies that colonialism is required to further the realization of universal freedom. Does this show that Hegel's conception of freedom is 


\section{Hegel and Colonialism}

necessarily bound up with his pro-colonialism? If so, then-taking it that colonialism was in fact morally wrong-presumably his conception of freedom and its historical development must be rejected (although not necessarily freedom as such, of course).

But perhaps that would be to dismiss Hegel's thought too summarily, and thereby to do disservice not only to Hegel but also to anti-colonial and decolonizing thought and activism, which, after all, has regularly drawn on Hegel, both directly-e.g., when Frantz Fanon ([1952] 2008) and Ngugi wa Thiong'o (2012) use Hegel to critique colonialism-and indirectly, through Hegel's influence on Marxism and critical theory. Moreover, Hegel's thought may still offer further anti-colonial resources which remain to be mined. We might therefore reasonably seek to separate Hegel's basic conception of freedom and its historicity from his Eurocentric narrative of history so that, when so separated, that basic conception tells against colonialism. Such a view-one that rescues Hegel from himself-is often adopted, more or less explicitly, by his interpreters. ${ }^{10} \mathrm{I}$ now want to set out my own version of this type of view, although I will go on to complicate it in Section IV.

The view is this. We can separate the essentials of Hegel's account of freedom from his concrete interpretation of the actual movement of history. Hegel was wrong and prejudiced when he dismissed Africans, indigenous Americans and Orientals as unfree and incapable of coming to freedom on their own. Nevertheless his basic account of what freedom is, including its necessary historical development, remains insightful. A better informed judgment of non-European peoples would require a very different historical narrative. But that does not undermine Hegel's basic points that freedom develops historically in tandem with the consciousness of it, as embodied in different cultures and social institutions. When we separate these basic points from his actual narrative, we find that these points serve a progressive purpose, yielding grounds to reject colonialism.

This view dovetails with Hegel's claim that the human capacity for selfdetermination is universal, not confined to Europeans (see, e.g., $H$ 88). Admittedly, though, this starting-point is only an abstract universal. Self-determination can be actualized only when one is conscious of one's capacity for it, and that requires social and cultural institutions, a whole way of life, which foster that consciousness. Such a way of life arose for the first time only in ancient Greece, for Hegel, so that actualized freedom does not obtain universally. Arguably, though, given his basic view of freedom and its historicity, Hegel could and should have interpreted all the world's regions as taking part in the gradual historical unfolding of social institutions that support freedom. Hegel does not do so because he denies that non-European peoples are conscious of freedom at all. Since non-European societies were not conscious of freedom 


\section{Alison Stone}

even in the restricted ways that the Greeks and Romans were, the former had no basis for moving forward historically by further advancing an already partly realized freedom.

Thus, what underpins Hegel's denial of historicity to non-European peoples is his sharp division of European freedom from non-European unfreedom. That in turn is underpinned by his claim that the ancient Greeks made the decisive break from unfreedom into freedom. The Greeks, Hegel says, became the distinctive people they were out of a mixing within them of heterogeneous Oriental peoples and their cultures, but the Greeks surmounted or overcame (ïberwinden) this background (HG 214). By doing so, the Greeks created their 'free, beautiful' spirit (374). The Greeks overcame their Oriental preconditions to 'make themselves' (372; see also 393-94).

However, this view that the Greeks 'overcame' the Oriental world of unfreedom seems overstated by Hegel's own lights. For Hegel himself, the Greeks mark only the latest phase in a growing consciousness of freedom running from China through India to Persia and culminating in Egypt, Persia's most advanced province. Egypt is the hinge between Orient and Occident, in which the human soul's intrinsic capacity for freedom was almost grasped. But it was not quite grasped, for the soul was still not distinguished from animal nature, a distinction the Greeks went on to make (HG 334, 368). That lack of distinction is shown by the way the Egyptians modelled their gods and goddesses on animal species, often with animal heads. Yet, for Hegel, the Greeks too stopped short of recognizing that all people have an inherent capacity for freedom. They admitted freedom only to male, native-born slave-owners. In that way their view of freedom remained intermingled with acceptance of natural contingency, i.e., accidents of birth, sex and geographical location ( $H$ 88). So the difference between the Egyptian view_human freedom is incompletely distinguished from (animal) nature — and the Greek view-human freedom is again incompletely distinguished from nature-appears to be a difference of degree, not kind. ${ }^{11}$

Hegel's 'overcoming' idea therefore sits uncomfortably with his graduated portrayal of history's stages. That portrayal could be taken to show that belief in freedom is not exclusively European, since the Persians and Egyptians already had versions of that belief. To be sure, they were inadequate versions (for Hegel) - but then so was the Greeks'. And by extension, the Indians and Chinese likewise had versions of the belief in freedom-even more inadequate ones, since they attributed freedom only to 'one', not 'some'-but where that inadequacy still differentiates these peoples from the Greeks only by degree and not kind (more so in the Indian case since the 'one' is a whole caste). If the Oriental peoples did have versions, however unsatisfactory, of the belief in freedom, then Hegel should not have denied that these peoples are historical. For if it is believed that someone is 


\section{Hegel and Colonialism}

free, be it only 'one' ruler or caste, then others may claim and demand that same freedom for themselves, powering historical change.

Now, Hegel regards the Africans and indigenous Americans as lacking freedom more radically than the Orientals, yet contrary evidence was available to him. He might, for instance, have noted the Iroquois Confederacy of five (later six) Native American tribes, founded c.1600 and dissolved c.1800: a system of intra- and inter-tribal governance which 'maximized individual freedom while seeking to minimize excess governmental interference in people's lives' (Johansen 1982: 9), influencing the American Constitution. And Hegel embellished, exaggerated and at times outright distorted his sources on Africa so as to portray a people without any respect for human life, freedom, or rights-more so than the sources suggested, and they were already unreliable (see Bernasconi 1998). ${ }^{12}$ The way was open to Hegel to recognize Africans and indigenous Americans as having views of freedom, even if he classed them as even less adequate than Oriental ones. With that those peoples would, like the Orientals, have had an entry to history.

Nonetheless, Hegel preserves his division of European freedom from nonEuropean unfreedom by counting all the European stages as stages of freedom, down to its lowest level, and all the non-European stages as stages of unfreedom, right up to where unfreedom is almost freedom, but not quite. But the placement of this dividing line appears arbitrary. Consider, for example, Hegel's view that Hindus are not conscious of their own freedom because they fail to distinguish themselves, as human agents from nature (HG 256, 273-81). On Hegel's account, as we've just seen, there are ways that the ancient Greeks did not fully extricate human agency from nature either, so- on his own terms - it is not clear that the difference here is one of kind (history versus non-history, freedom versus unfreedom) rather than degree (more or less freedom, more or less far along the historical path towards full freedom).

Hegel could and, it seems, should have interpreted much of his material as evidencing how non-European peoples have grasped and practised freedom, albeit imperfectly. We might still find this revised Hegelian narrative objectionable, assuming that it ranks non-European conceptions of freedom as less advanced than European ones. Yet once it is admitted that non-European peoples are historical in principle, Hegel would also have to trace how historical advances unfolded in those societies, so reinterpreting his material once again. Each continent would have its own history of progression in consciousness of freedom, rather than non-European continents merely paving the way for Europe. The several continents would have histories of freedom that run in parallel, rather than corresponding to more or less advanced phases of a single historical line that culminates in modern Europe. 


\section{Alison Stone}

Neither of these revised Hegelian narratives - the single line or parallel lines versions-supports colonialism, not even the single line model on which non-European peoples' native levels of freedom are, although real, yet deficient compared to European ones. By recognizing freedom, however unsatisfactorily, non-European cultures would still have the internal potential and motor to advance to greater freedom. In that case colonization would not be necessary for non-European peoples' achieving freedom, and would not be justified as a necessary step in the realization of universal freedom. Another plank in Hegel's justification of colonization is that colonized peoples enjoyed no freedom pre-colonization-so that, despite its abrogation of their freedom, colonization did not worsen their position (and ultimately would improve it). But if these peoples did have a grasp of freedom, however imperfect, then colonization stood to worsen their position. That risk is especially pronounced given Hegel's own perspective that some violence is necessary for colonization and, given the role of contingency in human affairs, that that violence may well mushroom beyond the necessary minimum. Further, for Hegel colonization requires the extirpation of native cultures; but if these are not cultures of unfreedom, then that extirpation is not justified. Apparently, then, Hegel should by his own lights have opposed colonialism, for his own philosophy generates a case against it.

\section{The Greeks, history and self-liberation from nature}

The view just canvassed is that, despite the Eurocentrism and pro-colonialism of Hegel's substantial narrative in the $\mathrm{PWH}$, his distinctive account of freedom, as developing historically through successive civilizations, does not in itself necessitate his substantive Eurocentrism and, when extricated from the latter, yields a case against colonialism. However, we can distinguish weaker and stronger versions of this view. More weakly: Hegel's basic account of freedom can be separated from his actual pro-colonialism, and so does not necessarily imply pro-colonialism, but contains anti-colonial possibilities as well as the pro-colonial possibilities that Hegel developed from it. More strongly: Hegel's basic account of freedom can be separated from his actual pro-colonialism and, when so separated, this account implies anti-colonialism and has an inherently anti-colonial direction. I endorse the weaker but not the stronger claim, and the weaker one only subject to a significant qualification: Hegel's basic account of freedom can be separated from his actual pro-colonialism, but not as easily as Section III suggested. This is because Hegel's conception of freedom as self-determination has significant connections with his Eurocentrism. 


\section{Hegel and Colonialism}

In Section III I suggested that Hegel's divisions Greeks/non-Greeks, free/ unfree look arbitrary. But actually they are not. For Hegel:

Its [Greece's] principle is that self-conscious freedom steps forth. ... [Regarding t] he unity of spirit with nature ... the specificity of this unity [in the Greek case] is to be grasped. One unity is the Oriental, ... consciousness immersed in nature; a [new kind of] harmony is now to be brought forth [by the Greeks] in which ... spirit dominates. Spirit now determines nature, and this is a spiritual unity ... (Hei 117; my emphases)

[The] fundamental characteristic [of the Greek spirit is] that the freedom of spirit is conditioned by and in essential relation to some natural stimulus. Greek freedom is stimulated by something other and is free because it changes and produces the stimulus from out of itself (aus sich). (S 238; my emphasis)

Thus, the Greeks were free in that they were at home with themselves in the other, i.e., nature. But this does not mean that the content of their practices and way of life was determined by natural givens such as the Greeks' given impulses. Rather, they reshaped these givens and so became at-home-with-themselves in them. In the Greek case, then, spirit 'determined' nature, whereas previously spirit had been immersed or absorbed (versenkt) in nature. This Greek determination of nature by spirit-spirit's investment of nature with meaning of its own — was made possible by a prior moment, first carried out by the Greeks, through which 'spirit is no longer immersed [versenket] in nature, ... [but] releas[es] itself from nature [sich losmachend von der Natur]' (HG 395-96). This moment in which the human spirit first releases or sets itself free from nature corresponds to the overcoming (überwinden) by the Greeks of their mixed ethnic heritage, a moment of overcoming through which they became able to remake that heritage for themselves, to make themselves. Hegel is explicit that none of the world's other peoples to that point had achieved this.

Even so, for Hegel, the Greeks exercised freedom always with respect to nature and existing givens in the world-re-shaping what they found already there, rather than creating a totally new world out of themselves. Hence the Greeks did not regard free individuals as being capable of adjudicating independently on the given natural and social world through their own reason, or of generating norms and principles purely through the exercise of their spiritual freedom. Or, as Hegel also puts it elsewhere, individual subjectivity was not differentiated from social substance, but the individual identified fully and unquestioningly with his or her social role, and there was no ground for 


\section{Alison Stone}

independent social criticism (see Hardimon 1993). Connected with all this, the Greeks restricted freedom to some people only, effectively stipulating that only those with certain kinds of nature-male, free-born — or natural location-native Greek-had the power of self-determination. In these ways spirit's freedom remained 'conditioned', or limited (bedingt), by—although not immersed innature (and see HG 390).

However, these limitations contradicted the essence of self-determination as the Greeks understood it, as including a moment of overcoming or settingoneself-free from nature, such that the power to overcome nature cannot possibly be limited by nature (or it would not be a power to overcome nature at all). Thus, in the principle of Greek freedom, inasmuch as it is freedom, it is implied that thought must be free for itself' (HG 268)—although the Greeks for a long time did not explicitly grasp or follow through on that implication. Nonetheless, in the end that contradiction was what made it possible for the Greeks' exclusion of some people from freedom, and their other ways of restricting freedom's scope, to come in for criticism. The criticism came with Socrates and the Sophists claiming that thought can adjudicate rationally on what is and generate norms by itself (417). In that freedom of thought was thereby grasped as fully independent of nature, it was also grasped as universal, at least in principle. In these two ways, 'Thought ... introduces an opposition [Gegensat:] [to the Greek mixture of freedom and nature] and asserts the validity of essentially rational principles' (S 267).

For Hegel, then, Greek culture enabled rational criticism of what is, including of limited freedom, as no pre-Greek cultures did, just because the Greeks had established a root opposition between freedom and nature, whereas 'in the Oriental states, in which a lack of opposition is present, no moral freedom can come about' (267). Although the advent of rational critique brought on the demise of Greek culture, Europe was thereby also set on the path of transformative historical change. We see, then, why in his own terms Hegel says that non-European peoples could not advance critical claims for freedom's extension but uncritically accepted the authority of their rulers-patriarchal authority in China, caste hierarchy and caste-based restrictions and rituals in India, and state power in Persia. Non-Europeans could not question such authorities because their cultures did not grasp freedom as including the moment of overcoming or setting-oneself-free from nature and the given. Because freedom was not grasped as including that moment of human separation from nature and the given, no contradiction was perceived in freedom being limited by nature, e.g., confined to people of certain castes, or by given states of affairs, e.g., customary authority and ritual. Non-Europeans lacked a critical motor to drive social change, hence lacked history proper-or indeed freedom as properly distinguished from unfreedom. 


\section{Hegel and Colonialism}

So, for Hegel, there is a genuine difference in kind, not merely degree, between the Greek and post-Greek European world on the one hand and the non-European world on the other; the Europe/non-Europe divide is not arbitrary but has a philosophical rationale. For while the Greek view of freedom was, like non-European views, limited and inadequate, the former was more advanced in one key respect- the inclusion in freedom of a primary moment of 'overcoming' nature-which enabled the Greek and post-Greek European world to become self-critical, self-revising, and so historical. This is what motivates Hegel to identify Greek and post-Greek European views as views of freedom, however limited, whereas non-European views that might prima facie look like views of freedom are still actually modes of unfreedom.

Once again, we might object that non-Europeans have at times construed freedom as including this moment of overcoming nature. Even on Hegel's account, Hindus appreciate the human power to abstract from the world in thought. He maintains, though, that this is merely an intellectual withdrawal and that when it comes to practical agency Hindus see human agency as immersed in, not including any moment of self-freeing-from, nature (see, e.g., S 157-58). In response we could, with Jaspal Peter Sahota (2016), agree that in classical Indian thought there has been a tendency to locate human agency within nature but argue, against Hegel, that this does not constitute a real absence of freedom but rather a different conception of freedom. We might then say that because these-and other-non-European views were still views of freedom, those views were still sufficient to motivate social criticism, and hence place nonEuropean peoples in history, even without the element of overcoming nature. However, such a position would take us further away from Hegel's own account of the historicity of freedom, according which, as we have seen, that moment of overcoming nature, uniquely new in ancient Greece, is crucial in powering historical progression.

Hegel's basic account of freedom and its historicity thus has more extensive and significant connections with his Eurocentrism than I suggested in Section III. In particular, that account connects with Hegel's denial that nonEuropean peoples are historical-i.e., can come to freedom on their own-and hence with his case for colonialism, as the only route along which those peoples can reach freedom. These connections suggest that, after all, we cannot straightforwardly take up Hegel's account of freedom and its historicity while sloughing off his pro-colonialism. This is not to say that we cannot separate out these parts of his thought at all. But rescuing Hegel from himself is set to be a complicated process, not quick or straightforward. To the extent that such a rescue is possible, Hegel's pro-colonialism cannot rightly be counted as necessary to his thought or system. Yet his pro-colonialism does have extensive and deep-seated connections with his other views-enough to show that it is not the 


\section{Alison Stone}

case that Hegel should not have endorsed colonialism by his own standards. Rather, he did and could endorse it coherently in his own terms, although other, anti-colonialist possibilities were also available within his own terms which he could have developed.

So the claim that Hegel's account of freedom is inherently anti-colonial is unduly strong. Through his understanding of freedom as involving spirit extricating itself from nature, that account has sustained links with his Eurocentrism and so his pro-colonialism. We can nonetheless envisage various manoeuvres by which to maintain that freedom develops historically for all the world's peoples, for example by saying that they have several conceptions of freedom where freedom can, but does not have to, include self-liberation from nature. Then ancient Greece would initiate one historical pathway to freedom, but not the only one. Even so, Hegel's own account of freedom and its historicity does not inherently drive us to make these intellectual manoeuvres, but only permits them. In sum, if Hegel's view of freedom does not necessarily imply pro-colonialism, neither is it inherently anti-colonial. We can make distinctions and qualifications within his thought so as to yield anti-colonial conclusions, but this is only one of several possible lines of development of which his thought admits, another being its elaboration into the Eurocentric and pro-colonial system that Hegel in fact forged.

There is a broader moral. We-i.e., the heirs of the European heritage that runs through philosophy into modern political thought-should not let this heritage off the hook too easily. This heritage, including Hegel's thought, has been implicated in colonialism in various ways. To be sure, because it extols and articulates the values of freedom and equality, this heritage also furnishes conceptual resources for critiquing colonialism and giving support to anticolonial struggles, and anti-colonial thinkers and activists have drawn on modern European ideas for this purpose. For example, the Haitian revolutionaries declared that they were acting in allegiance to the emancipatory goals of the French Revolution. This might lead us to suppose that the European political legacy is intrinsically liberatory, and that theorists in the European traditionHegel included-have only ever justified colonialism due to unfortunate prejudices that led them to go back on their own principles.

I believe that taking that view exculpates our predecessors too quickly, and leaves us at risk of inadvertently embracing ideas inherited from these predecessors which actually have deep-rooted internal connections with Eurocentric and pro-colonial attitudes. This is not to say that we should or could repudiate these ideas outright. Rather, in view of their connections with colonialism, we need to think carefully and critically about how far to take these inherited ideas forward and how we might do so differently. My aim has been to help us cultivate this caution in Hegel's case by acknowledging that, while his 


\section{Hegel and Colonialism}

thought harbours anti-colonial possibilities, it also has real and tenacious links with colonialism of which we should remind mindful. ${ }^{13}$

\section{Alison Stone \\ Lancaster University, UK \\ a.stone@1ancaster.ac.uk}

\section{Notes}

1 Contributions include those by Bernasconi 1998, 2007, 2016, Bonetto 2006, de Laurentiis 2014, McCarney and Bernasconi 2003, Mowad 2013, Parekh 2009, Purtschert 2010 and Tibebu 2010.

2 However, see Buck-Morss 2000, and-for highly critical accounts-Dussel [1992] 1995 and 1993, Guha 2002, Tibebu 2010. Also relevant are Bird-Pollan 2014 (on Hegel and Fanon), Brennan 2013 (on Hegel's influence on post-colonialism), Buchwalter 2009 (defending Hegel against charges of Eurocentrism), Monahan 2017 (Creolizing Hegel) and Serequeberhan 1989 (on colonialism in the Philosopby of Right).

3 Ranajit Guha identifies another argument for colonialism in the Philosophy of Right, from the 'rights' that Hegel claims civilized nations have with respect to less advanced ones (PR §351, 376). These rights, Guha argues, are 'rights of conquest', noting Hegel's praise for British military victories over India led by Robert Clive (1725-74), whose conquests established the East India Company's rule over Bengal and other Indian states. See Guha 2002: 43-44; PR §372A, 364 and 474 note 1$)$.

Abbreviations used:

EN= Hegel, G. W. F. (1970), Philosophy of Nature, trans. A. V. Miller. Oxford: Clarendon Press.

EM = Hegel, G. W. F. (1971), Philosophy of Mind. Trans. W. Wallace and A. V. Miller. Oxford: Oxford University Press. Cited by paragraph and page number.

N=Hegel, G. W. F. (1975), Lectures on the Philosophy of World History: Introduction: Reason in History, trans. H. B. Nisbet. Cambridge, UK: Cambridge University Press.

$S=$ Hegel, G. W. F. (1991), The Philosopby of History, trans. J. Sibree. Buffalo, NY: Prometheus Books. PR = Hegel, G. W. F. (1992), Elements of the Philosophy of Right, trans. H. B. Nisbet. Cambridge, UK: Cambridge University Press.

Hei=Hegel, G. W. F. (2005) Die Philosophie der Geschichte: Vorlesungsmitschrift Heimann (Winter 1830/1831), ed. K. Vieweg. Berlin: Wilhelm Fink.

${ }^{4}$ Hegel lectured on the PWH in 1822/23, 1824/25, 1826/27, 1828/29 and 1830/31. His manuscripts of the Introduction from 1822 (rev. 1828) and 1830/31 survive, as do many transcripts, between them covering every course. Some, such as de Laurentiis (2014), are wary of directly attributing to Hegel views, notably on race, expressed only in the transcripts. I agree that we should disambiguate sources, but where multiple independently written transcripts 


\section{Alison Stone}

converge, as do-extensively - several transcripts of the PWH, we may take them to be reliable. Accordingly, I refer to: Hegel's manuscripts (abbreviated H) as in Hegel 2011, which is the English translation of the corresponding volume of the Gesammelte Werke (Hegel 1995); and the integrated text of the 1822/23 course composed primarily from Hotho's and Griesheim's transcripts (abb. HG), included in Hegel 2011 (the German is Hegel 1996). Since the German critical edition of the transcripts remains incomplete, for materials on Hegel's later courses I have used Heimann's transcript of 1830/31 whenever possible (Hegel 2005; abb. Heı), otherwise the composite texts produced by Karl Hegel (Hegel 1986) and translated by Sibree (Hegel 1991; abb. S) and by Georg Lasson/Johannes Hoffmeister (Hegel 1988), translated by Nisbet (Hegel 1975; abb. N). I quote English translations whenever available, sometimes adjusted in view of the German.

${ }^{5}$ For more on contingency in Hegel, see, inter alia, Burbidge 2007: esp. ch. 1. Burbidge stresses the extent to which Hegel 'takes the contingencies of history seriously' (2007: 9).

${ }^{6}$ For Hegel, 'nature ... is indeed a rational system, operating in its own distinct element' (N 44). The division into continents is rational in that different natural features and their varietiesmountains and plains, lands and seas, and their fusion and differentiation-each find full embodiment in different continents (EM \$393 and R, 40-41). In a sense, then, non-Europeans are subject to reason and rational progression insofar as nature imposes it on them from the outside rather than by exercising rational thought for themselves. This coheres with Hegel's view that these peoples are immersed in nature, out of which only Europeans can lift them; see below.

7 This recalls Hegel's derivation of time from space in the Philosophy of Nature, a derivation that positions time as more advanced than space (EN $\$ \$ 256-57,31-36$ ).

8 This is evident from, e.g., Hegel's discussion of the colonization of America; see Section II.

${ }^{9}$ Hegel connects formation with possession (PR \$56, 85-86), albeit in the very different context of modern European societies in which private property is institutionalized. I leave unexplored here how far his ideas about slavery's educative power may be informed by his lord/bondsman dialectic.

${ }^{10}$ For instance, some interpreters defend Hegel against charges of Eurocentrism and racism (e.g., Buchwalter 2009, Houlgate [1991] 2015: 35-37, McCarney in McCarney and Bernasconi 2003, Mowad 2013); others stress Hegel's founding importance for anti-colonial thought (Brennan 2013); and numerous readers of Hegel as a thinker of freedom (e.g., Patten 1999) see no need to discuss his position on colonialism, presumably on the grounds that the latter is a merely accidental, avoidable part of his thought from which his essential views on freedom can be extracted.

11 For Hegel, the Greeks were greatly influenced by the Egyptians, whose influence they nonetheless overcame. Here he is close to accepting what Martin Bernal calls the 'ancient model' of the Greeks' origins, a model to which the Greeks themselves adhered; laternineteenth-century Europeans instead espoused an 'Aryan model', on which Greek culture proper arose from northern invaders driving out earlier Egyptian and Phoenician influences ([1987] 1991). Bernal argues that the Aryan model had Eurocentric motivations: if the Greeks, 


\section{Hegel and Colonialism}

the supposed originators of Europe's distinctive culture, were actually the Egyptians' heirs, then, given that Egypt is within Africa, the Europe/Africa divide would crumble. A further complicating factor is whether the Egyptians were seen as black Africans. Bernasconi (2007) argues that Hegel thought so, as did most other Europeans of his time. Later the Egyptians' racial status was changed — to Mediterranean (i.e., Caucasian) — to hold up the divide between Europe-as-white and Africa-as-black. Bernasconi suggests that Hegel himself dealt with the potential anomaly_ of highly cultured black Africans giving much to the Greeks_-by making the Egypt/Greece transition the site of the key conceptual transition from unfreedom to freedom, nature to spirit (2007: 212-13). This ties in with my argument in Section IV that Hegel actually did have grounds, on his own terms, to construe the apparently gradual Egypt/ Greece transition as actually being a sharp divide.

12 Bernasconi (2016) has recently shown how Hegel likewise distorted his sources on China, to the detriment of the Chinese.

${ }^{13}$ I thank Bob Stern and the referees for their helpful comments on earlier versions.

\section{Bibliography}

Bernal, M. [1987] (1991), Black. Athena: The Afroasiatic Roots of Classical Civilisation, Vol. 1. London: Vintage.

Bernasconi, R. (1998), 'Hegel at the Court of the Ashanti', in S. Barnett (ed.), Hegel After Derrida. Albany NY: SUNY.

Bernasconi, R. (2007), 'The Return of Africa: Hegel and the Question of the Racial Identity of the Egyptians', in P. T. Grier (ed.), Identity and Difference. Albany NY: SUNY.

Bernasconi, R. (2016), 'China on Parade: Hegel's Manipulation of his Sources and his Change of Mind', in B. Brandt and D. L. Purdy (eds.), China in the German Enlightenment. Toronto: University of Toronto Press.

Bird-Pollan, S. (2014), Hegel, Freud and Fanon: The Dialectic of Emancipation. London: Rowman and Littlefield International.

Bonetto, S. (2006), 'Race and Racism in Hegel—An Analysis', Minerva: An Internet Journal of Philosophy 10.

Brennan, T. (2013), 'Hegel, Empire, and Anti-Colonial Thought', in G. Huggan (ed.), The Oxford Handbook of Postcolonial Studies. Oxford: Oxford University Press. Buchwalter, A. (2009), 'Is Hegel's Philosophy of History Eurocentric?', in W. Dudley (ed.), Hegel and History. Albany NY: SUNY.

Buck-Morss, S. (2000), 'Hegel and Haiti', Critical Inquiry 26:4: 821-65.

Burbidge, J. (2007), Hegel's Systematic Contingency. Basingstoke: Palgrave Macmillan. De Laurentiis, A. (2014), 'Race in Hegel: Text and Context', in M. Egger (ed.), Philosophie Nach Kant: Neue Wege zum Verständnis von Kants Transžendental- und Moralphilosophie. Berlin: De Gruyter. 


\section{Alison Stone}

Dussel, E. [1992] (1995), The Invention of the Americas, trans. M. D. Barber. New York: Continuum.

Dussel, E. (1993), 'Eurocentrism and Modernity', Boundary 2 20:3: 65-76.

Fanon, F. [1952] (2008), Black Skin, White Masks, trans. R. Philcox. New York: Grove.

Guha, R. (2002), History at the Limit of World-History. New York: Columbia University Press.

Hardimon, M. (1993), Hegel's Social Philosophy. Cambridge: Cambridge University Press.

Hegel, G. W. F. (1970), Philosophy of Nature, trans. A. V. Miller. Oxford: Clarendon.

Hegel, G. W. F. (1971), Philosophy of Mind, trans. W. Wallace and A. V. Miller. Oxford: Oxford University Press.

Hegel, G. W. F. (1975), Lectures on the Philosophy of World History: Introduction: Reason in History, trans. H. B. Nisbet. Cambridge: Cambridge University Press.

Hegel, G. W. F. (1986), Vorlesungen über die Philosophie der Geschichte. Werke Vol. 12, ed. E. Moldenhauer and K. M. Michel. Frankfurt: Suhrkamp. [English translation: Sibree.]

Hegel, G. W. F. (1988), Vorlesungen über die Philosophie der Weltgeschichte Vols. 1-3, ed. G. Lasson. Vols. 1-4. Hamburg: Meiner. [English translation of volume 1: Nisbet.] Hegel, G. W. F. (1991), The Philosophy of History, trans. J. Sibree. Buffalo NY: Prometheus Books.

Hegel, G. W. F. (1992), Elements of the Philosophy of Right, trans. H. B. Nisbet. Cambridge: Cambridge University Press.

Hegel, G. W. F. (1995), 'Vorlesungen über die Philosophie der Weltgeschichte: Einleitung', in W. Jaeschke (ed.), Vorlesungsmanuskripte II (1916-1831). Gesammelte Werke Vol. 18. Hamburg: Meiner. [English translation: Brown and Hodgson.]

Hegel, G. W. F. (1996), Vorlesungen über die Philosophie der Weltgeschichte, Berlin 1822/ 23. Nachschriften von Griesheim, Hotho und Kebler, ed. Karl Brehmer, K.-H. Ilting und Hoo Nam Seelmann. Hegel: Vorlesungen: Ausgew. Nachscbriften und Manuskripte Vol. 12. Hamburg: Meiner. [English translation: Brown and Hodgson.]

Hegel, G. W. F. (2005), Die Philosophie der Geschichte: Vorlesungsmitschrift Heimann (Winter 1830/1831), ed. K. Vieweg. Berlin: Wilhelm Fink. Abb. Hei.

Hegel, G. W. F. (2011), Lectures on the Philosophy of World History: Volume 1: Manuscripts of the Introduction and the Lectures of 1822-3, ed. and trans. R. F. Brown and P. C. Hodgson, with assistance of W. G. Geuss. Oxford: Clarendon Press. Houlgate, S. [1991] 2015, An Introduction to Hegel: Freedom, Truth and History. Oxford: Blackwell.

Johansen, B. E. (1982), Forgotten Founders: How the American Indians Helped Shape Democracy. Boston: Harvard Common Press. 


\section{Hegel and Colonialism}

McCarney, J. and Bernasconi, R. (2003), 'Exchange: Hegel's Racism?', Radical Philosophy 119(May/June): 32-37.

Monahan, M. (ed.) (2017), Creolizing Hegel. London: Rowman and Littlefield International.

Mowad, N. (2013), 'The Place of Nationality in Hegel's Philosophy of Politics and Religion: A Defense of Hegel on the Charges of National Chauvinism and Racism', in A. Nuzzo (ed.), Hegel on Religion and Politics. Albany NY: SUNY.

Parekh, S. (2009), 'Hegel's New World: History, Freedom, and Race', in W. Dudley (ed.), Hegel and History. Albany NY: SUNY.

Patten, A. (1999), Hegel's Idea of Freedom. Oxford: Oxford University Press.

Purtschert, P. (2010), 'On the Limit of Spirit: Hegel's Racism Revisited', Philosophy and Social Criticism 36:9: 1039-51.

Quijano, A. (2000), 'Coloniality of Power, Eurocentrism, and Latin America', Nepantla: Views from South 1:3: 533-80.

Sahota, J. P. (2016), 'Hegel's Critique of Hinduism: A Response', Hegel Bulletin 37:2: 305-17.

Serequeberhan, T. (1989), 'The Idea of Colonialism in Hegel's Philosophy of Right', International Philosophical Quarterly 29:3: 301-18.

Shohat, E. and Stam, R. [1994] (2014), Unthinking Eurocentrism. New York: Routledge.

Tibebu, T. (2010), Hegel and the Third World: The Making of Eurocentrism in World History. Syracuse NY: Syracuse University Press.

Wa Thiong'o, N. (2012), Globalectics: Theory and the Politics of Knowing. New York: Columbia University Press. 